Habits of the Heartland 



\title{
Habits of the Heartland
}

Small-Town Life in Modern America

\author{
Lyn C. Macgregor
}

Cornell University Press

ITHACA AND LONDON 
Copyright @ $\odot 2010$ by Cornell University

All rights reserved. Except for brief quotations in a review, this book, or parts thereof, must not be reproduced in any form without permission in writing from the publisher. For information, address Cornell University Press, Sage House, 512 East State Street, Ithaca, New York 14850.

First published 2010 by Cornell University Press

First printing, Cornell Paperbacks, 2010

Printed in the United States of America

\section{Library of Congress Cataloging-in-Publication Data}

Macgregor, Lyn Christine, 1973-

Habits of the heartland : small-town life in modern America / Lyn C.

Macgregor.

p. $\mathrm{cm}$.

Includes bibliographical references and index.

ISBN 978-0-8014-4836-2 (cloth : alk. paper) — ISBN 978-0-8014-7643-3 (pbk. : alk. paper)

1. Viroqua (Wis.) - Social life and customs. 2. Viroqua (Wis.) -

Commerce-Social aspects. 3. Community life-Wisconsin-Viroqua.

4. City and town life-Wisconsin-Viroqua. I. Title.

F589.V57M33 2010

$977.5^{\prime} 73-\mathrm{dc} 22 \quad 2009045343$

Cornell University Press strives to use environmentally responsible suppliers and materials to the fullest extent possible in the publishing of its books. Such materials include vegetable-based, low-VOC inks and acid-free papers that are recycled, totally chlorine-free, or partly composed of nonwood fibers. For further information, visit our website at www.cornellpress.cornell.edu.

$\begin{array}{lllllllllll}\text { Cloth printing } & 10 & 9 & 8 & 7 & 6 & 5 & 4 & 3 & 2 & 1\end{array}$

$\begin{array}{lllllllllll}\text { Paperback printing } & 10 & 9 & 8 & 7 & 6 & 5 & 4 & 3 & 2 & 1\end{array}$ 
This book is dedicated to the people of Viroqua 
